\title{
Editorial
}

\section{Do odontogenic tumors occur even in the dental clinic?}

NANCy Alfieri Nunes

Among the intra-osseous lesions, we find the root cysts very frequently. Due to the inflammatory process and involvement of the pulp, it is known to dentists. However, when think about odontogenic tumors, the frequent, painless odontoma often discovered on routine radiographs may come to mind. Easy to diagnose when compound. ${ }^{1}$

But what about other tumors derived from dental tissues?

Ameloblastoma is a benign and relatively common neoplasm (10 to $49 \%$ of odontogenic tumors) $)^{1,2,3}$, originated of odontogenic epithelium, it may involve soft tissues (peripheral ameloblastoma) ${ }^{4}$ or bone tissue of the maxilla and mandible, with a higher incidence in the mandible, with variable forms and histopathological classification, observed in young in the second and third decades of life or later. ${ }^{1,2,3}$ The radiographic and imaging aspects they may be unilocular or multilocular, resembling cystic lesion $^{5,6}$ or multiple radiolucent areas ${ }^{2}$.

Ameloblastomas present several histopathological types and the diagnosis allows more or less invasive treatments, since they tend to recur frequently ${ }^{7}$. From the damage produced to extensive surgeries and the need for reconstruction, it is noted that there are also cases of its correlation with squamous cell carcinomas in the mandible ${ }^{6}$, the behavior of ameloblastomas is considered more or less aggressive ${ }^{7}$.

The diagnosis of this type of odontogenic tumor is histopathological and immunoistiquimic, whith positivity identified for CK19 and p634; BRAF V600E mutation RAS, FGFR2 or $\mathrm{SMO}^{7}$.

Histopathological variations for World Health Organization, it is solid or multicystic and unicystic ${ }^{5,7}$. Subtypes as plexiform, desmoplastic, follicular and acanthomatous are described. Unictics type have a less aggressive behavior ${ }^{3}$. Jaw injuries are more frequent than in the maxilla. Recurrences are associated with mutations, which are more frequent in this region?

\section{REFERÊNCIAS}

1 Ahire MS, Tupkari JV, Chettiankandy TJ, Thakur A, Agrawal RR. Odontogenic tumors: A 35-year retrospective study of 250 cases in an Indian (Maharashtra) teaching institute. Indian J Cancer. 2018 Jul-Sep;55(3):265-272. https://www.ncbi.nlm.nih. gov/pubmed/30693892

2 Nolabolu GRK, Mohiddin A, HIremathi SKF, Manyan R, Bharath TS, Raju Pr. Epidemiologica, study of odontogenic tumours: An institucional experience. J Inf Publi Health. 2017, 10:324-330.

https://www.ncbi.nlm.nih.gov/pubmed/27425795

3 Menditti D, Laino L, De Marco G, De Rosa A, Mellone P, Baldi A. Unicystic ameloblastoma of the mandible.2011, In Vivo, 25: 125-18.

http://iv.iiarjournals.org/content/25/1/125.full.pdf

4 Kaneko T, Nakamura S, Kawano R, Horie N, Shimoyama T. Peripheral ameloblastoma of the mandible: A case report. J Oral Maxilofac Surg Med Pathol. 2016; 28 (6):565-568.

https://www.sciencedirect.com/science/article/abs/ pii/S2212555816000090?via\%3Dihub

5 Iwase $\mathrm{M}$ et al. Hybrid Desmoplastic/Follicular Ameloblastoma of the Mandible: A Case Report and Review of the Literature. Case Rep Pathol. 2017; 1-6. https://scinapse.io/journals/2764691556?p=5

6 Hijioka $\mathrm{H}$ et al. Primary intraosseous squamous cell carcinoma arising from ameloblastoma of the mandible: A case report. J Oral Maxilofac Surg Med Pathol. 2015, 27(5):693-697.

https://www.ncbi.nlm.nih.gov/pmc/articles/ PMC3660158/

7 Heikinheimo K et al. The Mutational Profile of Unicystic Ameloblastoma. J Dental Res. 2019, 98 (1):54-60 https://www.ncbi.nlm.nih.gov/pubmed/30216733 